\title{
Effect of Fertilizer Management in Combination with Soil Conditioner on Yield of Cassava Cultivated on Coarse-Textured Soil in Thailand
}

\author{
Pongpet Pongsivapai ${ }^{1}$, Chaisit Thongjoo ${ }^{1}$, Jutamas Romkaew ${ }^{2} \&$ Tawatchai Inboonchuay ${ }^{1}$ \\ ${ }^{1}$ Department of Soil Science, Faculty of Agriculture at Kamphaeng Saen, Kasetsart University, Kamphaeng \\ Saen Campus, Nakhon Pathom, Thailand \\ ${ }^{2}$ Department of Agronomy, Faculty of Agriculture at Kamphaeng Saen, Kasetsart University, Kamphaeng Saen \\ Campus, Nakhon Pathom, Thailand \\ Correspondence: Chaisit Thongjoo, Department of Soil Science, Faculty of Agriculture at Kamphaeng Saen, \\ Kasetsart University, Kamphaeng Saen Campus, Nakhon Pathom, Thailand. E-mail: thongjuu@yahoo.com
}

Received: July 15, 2016

Accepted: July 26, 2016

Online Published: August 18, 2016

doi:10.5539/mas.v10n11p239

URL: http://dx.doi.org/10.5539/mas.v10n11p239

The research is financed by Graduate School of Kasetsart University, Thailand.

\begin{abstract}
This study was conducted to determine the effect of fertilizer management in combination with soil conditioner (zeolite, pumice and organic fertilizer) on yield of cassava var. Huay Bong 60 cultivated on coarse-textured soil in Thailand. The experiment was arranged in a randomized complete block design. The results revealed that addition of chemical fertilizer combined with organic fertilizer rate $1,018.75 \mathrm{~kg} \mathrm{ha}^{-1}$ gave the highest plant height, above ground biomass, fresh tuber yield, starch content, starch yield and concentration of primary nutrient in fresh tuber yield and were not difference from addition of $100 \%$ chemical fertilizer combined with zeolite rate $312.5 \mathrm{~kg} \mathrm{ha}^{-1}$ $(\mathrm{P} \leq 0.01)$. After experiment, it was found that all treatments comprising sole chemical fertilizer at various rates or combined with soil conditioners were found to influence soil properties; soil $\mathrm{pH}$ was moderately to slightly acid, electrical conductivity $\left(\mathrm{EC}_{\mathrm{e}}\right)$ was non-saline soil, low to moderately low organic matter in soil, moderately low to moderate cation exchange capacity (CEC), low to moderate available $\mathrm{P}$ in soil; very low exchangeable $\mathrm{K}$ in soil.
\end{abstract}

Keywords: fertilizer, soil conditioner, cassava, coarse textured soil, zeolite, pumice, organic fertilizer

\section{Introduction}

Cassava is one of the very importance economic crops in Thailand because Thailand is the leading cassava exporter in the world. The situation of cassava demand in the world will increase in the future as animal feed and energy crops for bioethanol production. In 2013, Office of Agricultural Economics of Thailand reported 1.45 million ha planting area of cassava in Thailand, mostly located in northeast region of Thailand ( 0.75 million ha) where the soils were coarse-textured in this region (Kaewkamthong et al., 2014; Office of Agricultural Economics [OAE], 2014). Naturally, coarse-textured soils were characterized in weak structure, soil texture range from sand or loamy sand, low water holding capacity, soil $\mathrm{pH}$ range between $5-6$, organic matter lower than $1 \%$, low fertility and low cation exchange capacity. All these characteristics will contribute major problem of plant nutrient leaching, causing loss of nutrients from cassava root zone (Duangpatra, 1988; Tongglum et al., 2000; Astier et al., 2006; Kaewkamthong et al., 2014). In fact, cassava is very drought tolerant and grows better than other crops on coarse-textured soils of low fertility, providing a more stable income for poor farmers who farmed on eroded and/or infertile soils. Moreover, cassava or any other crop has been cultivated continuously on a low fertility soil without adequate application of fertilizer, manure or any soil amendment, therefore soil fertility will continually decrease, result in yield decline due to loss of nutrients by crop removal and leaching. Although, cassava extracts large amount of nutrients, especially $\mathrm{K}$ (following by $\mathrm{N}$ and $\mathrm{P}$ ) from soil. This is because of its high level of productivity of cassava tubers (Howeler, 1991; Putthacharoen et al., 1998; Anusontpornperm et al., 2005). So insufficient addition and leaching of plant nutrient are major problems affecting cassava yield in northeast regions, ranging them the lowest among other cassava producing regions (OAE, 2014). Farmers should at least be aware of the long-term detrimental effect on soil productivity and should imply some soil management practices such as minimum tillage, closer plant spacing, mulching, fertilizer application, intercropping, planting of contour live 
barriers and soil conditioners application, which result in an improved soil structure that allow plant roots to absorb plant nutrient better (Putthacharoen et al., 1998; Buarach et al., 2014). It is very important to examine the appropriate soil conditioners that can reduce leaching of plant nutrient and maintaining water in coarse-textured soil (Chen et al., 2016). Soil conditioner can be anything from natural source to synthetic materials used for improvement of soil chemical or soil physical properties or both. There were bountiful reports in many countries dealing with application of soil conditioners to improved soil properties, water retention, and yield of crops (Warrington et al., 1989; Agassi et al., 1990; Duangpatra, 2010). Also, there were many researches on applying soil conditioners to improve yield of economic crops or soil properties such as, zeolite and it was found that crop yield was increase and nutrient use efficiency was promoted. Other possible uses being investigated included applications as a carrier of slow-release fertilizers, insecticides, fungicides, and herbicides, and as a trap for heavy metals in soils. Research efforts are underway in many countries to exploit the potential of zeolites for the maintenance of plant nutrient and soil productivity (Ramesh \& Reddy, 2011; Gholamhoseini et al., 2013). Research on other conditioner indicated beneficial effects from pumice for its rich pore structure, strong water absorbent capacity, reducing nitrogen loss and high CEC, absence of aluminum toxicity and promotion of $\mathrm{P}$ retention (Gama et al., 2000; Wu et al., 2015). Organic fertilizer can retain water and helps soil particles to bind and resist against soil compaction. Preservation of an adequate amount of soil organic matter stabilized soil structure which made the soil more resistant to degradation (Celik et al., 2010). So this study was conducted to determine the effect of fertilizer management in combination with soil conditioners; zeolite, pumice and organic fertilizer on growth, yield, yield components of cassava and soil properties after harvested.

\section{Method}

\subsection{Study Area and Land Preparation}

Field experiment was performed on coarse-textured soil in a farmer's field at Dan Makham Tia, Kanchanaburi province. Properties of topsoil prior to conducting the experiment were revealed that the soil was slightly acid, non-saline, very low amounts of organic matter, low available $\mathrm{P}$, very low exchangeable $\mathrm{K}$, cation exchange capacity was very low, available water capacity was $6.08 \%$ by mass and soil texture was loamy sand as given in Table 1. The experiment was arranged in a randomized complete block design with 9 treatments 3 replications; control (no fertilizer and soil conditioner) (T1), chemical fertilizer 100\% (T2), chemical fertilizer $100 \%$ combined with zeolite (T3), chemical fertilizer $100 \%$ combined with pumice (T4), chemical fertilizer combined with organic fertilizer rate $1,018.75 \mathrm{~kg} \mathrm{ha}^{-1}$ (T5), chemical fertilizer $75 \%$ (T6), chemical fertilizer $75 \%$ combined with zeolite (T7), chemical fertilizer 75\% combined with pumice (T8) and chemical fertilizer combined with organic fertilizer rate $762.5 \mathrm{~kg} \mathrm{ha}^{-1}$ (T9). The description of treatment was show in Table 2.

Table 1. Initial properties of soil used in this experiment

\begin{tabular}{lc}
\hline Soil properties & Topsoil $(0-30 \mathrm{~cm})$ \\
\hline $\mathrm{pH}\left(1: 1 \mathrm{H}_{2} \mathrm{O}\right)$ & 6.15 \\
Electrical conductivity, $\mathrm{EC}_{\mathrm{e}}\left(\mathrm{dS} \mathrm{m}^{-1}\right)$ & 0.22 \\
Organic matter $(\%)$ & 0.45 \\
Available $\mathrm{P}\left(\mathrm{mg} \mathrm{kg}^{-1}\right)$ & 5.13 \\
Exchangeable K $\left(\mathrm{mg} \mathrm{kg}^{-1}\right)$ & 16.62 \\
Cation exchange capacity $\left(\mathrm{cmol} \mathrm{kg}^{-1}\right)$ & 2.42 \\
Available water capacity, AWCA $(\%$ by mass) & 6.08 \\
Texture & loamy sand \\
\hline
\end{tabular}

\subsection{Cassava Planting, Chemical Fertilizer and Soil Conditioner Preparation}

Huay Bong 60 cultivation by using cassava stake cutting, $20 \mathrm{~cm}$ long, were planted on top of ridge at spacing of $1 \times 1 \mathrm{~m}$. Chemical fertilizer applied following recommended fertilizer based on soil analysis (Department of Agriculture [DOA], 2005) as were given in Table $3\left(100-50-100 \mathrm{~N}_{-} \mathrm{P}_{2} \mathrm{O}_{5}-\mathrm{K}_{2} \mathrm{O} \mathrm{kg} \mathrm{ha}{ }^{-1}\right)$ for T2-T4. Chemical fertilizer $75 \%$ of soil analysis $\left(75-37.5-75 \mathrm{~N}^{-} \mathrm{P}_{2} \mathrm{O}_{5}-\mathrm{K}_{2} \mathrm{O} \mathrm{kg} \mathrm{ha}{ }^{-1}\right)$ for T6-T8. T5 and T9 applied chemical fertilizer rate 75.06-0-83.81 and 56.38-0-62.88 N-P $\mathrm{P}_{2}-\mathrm{O}_{2} \mathrm{O} \mathrm{kg} \mathrm{ha}{ }^{-1}$ respectively, half of the total amount was applied to cassava root zone at 2 and 4 month after planting. Soil conditioner was added to cassava root zone at 2 month; for T3 and T7 zeolite was applied at $312.5 \mathrm{~kg} \mathrm{ha}^{-1}$, T4 and T8 pumice was applied at $312.5 \mathrm{~kg} \mathrm{ha}^{-1}$ and for T5 and T9 organic fertilizer was applied at $1,018.75$ and $762.5 \mathrm{~kg} \mathrm{ha}^{-1}$, respectively. Cation exchange capacity of zeolite and pumice was 100-300 and $30 \mathrm{cmol} \mathrm{kg}^{-1}$, respectively (Panuccio et al., 2009; Duangpatra, 2010). Properties of 
organic fertilizer; $\mathrm{pH}$ was 6.30, electrical conductivity (EC) was $3.97 \mathrm{dS} \mathrm{m}^{-1}$, organic matter (OM) was $30.89 \%$, Total $\mathrm{N}, \mathrm{P}_{2} \mathrm{O}_{5}$ and $\mathrm{K}_{2} \mathrm{O}$ were $2.45,4.91$ and $1.95 \%$, respectively.

Table 2. Treatment description

\begin{tabular}{|c|c|c|}
\hline Treatment & Description & $\mathrm{N}-\mathrm{P}_{2} \mathrm{O}_{5}-\mathrm{K}_{2} \mathrm{O} \mathrm{kg} \mathrm{ha}^{-1}$ \\
\hline $\mathrm{T} 1$ & Control (no fertilizer+no soil conditioner) & $0-0-0$ \\
\hline $\mathrm{T} 2$ & Chemical fertilizer $100 \%$ & $100-50-100$ \\
\hline $\mathrm{T} 3$ & Chemical fertilizer $100 \%+$ Zeolite rate $312.5 \mathrm{~kg} \mathrm{ha}^{-1}$ & $100-50-100$ \\
\hline $\mathrm{T} 4$ & Chemical fertilizer $100 \%+$ Pumice rate $312.5 \mathrm{~kg} \mathrm{ha}^{-1}$ & $100-50-100$ \\
\hline T5 & Chemical fertilizer $75.06-0-83.81+$ Organic fertilizer rate $1,018.75 \mathrm{~kg} \mathrm{ha}^{-1}$ & $100-50-100$ \\
\hline T6 & Chemical fertilizer $75 \%$ & $75-37.5-75$ \\
\hline $\mathrm{T} 7$ & Chemical fertilizer $75 \%+$ Zeolite rate $312.5 \mathrm{~kg} \mathrm{ha}^{-1}$ & $75-37.5-75$ \\
\hline $\mathrm{T} 8$ & Chemical fertilizer $75 \%+$ Pumice rate $312.5 \mathrm{~kg} \mathrm{ha}^{-1}$ & $75-37.5-75$ \\
\hline T9 & Chemical fertilizer ${ }_{56.38-0-62.88}+$ Organic fertilizer rate $762.5 \mathrm{~kg} \mathrm{ha}^{-1}$ & $75-37.5-75$ \\
\hline
\end{tabular}

Table 3. Recommended rates of fertilizer based on soil analysis for cassava

\begin{tabular}{lcc}
\hline \multicolumn{2}{c}{ Soil properties } & Rates of fertilizer \\
\hline Organic matter (\%) & & \\
& $<1$ & $\mathrm{~N} 100 \mathrm{~kg} \mathrm{ha}^{-1}$ \\
& $1-2$ & $\mathrm{~N} 50 \mathrm{~kg} \mathrm{ha}^{-1}$ \\
\hline Available P $\left(\mathrm{mg} \mathrm{kg}^{-1}\right)$ & $\mathrm{N} \mathrm{25} \mathrm{kg} \mathrm{ha}$ \\
& $<7$ & \\
& & $\mathrm{P}_{2} \mathrm{O}_{5} 50 \mathrm{~kg} \mathrm{ha}^{-1}$ \\
& $\mathrm{P}_{2} \mathrm{O}_{5} 25 \mathrm{~kg} \mathrm{ha}^{-1}$ \\
& $\mathrm{P}_{2} \mathrm{O}_{5} 0 \mathrm{~kg} \mathrm{ha}^{-1}$ \\
\hline Exchangeable $\mathrm{K}\left(\mathrm{mg} \mathrm{kg}^{-1}\right)$ & \\
& \\
& $\mathrm{K}_{2} \mathrm{O} 100 \mathrm{~kg} \mathrm{ha}^{-1}$ \\
& $\mathrm{~K}_{2} \mathrm{O} 50 \mathrm{~kg} \mathrm{ha}^{-1}$ \\
& $\mathrm{~K}_{2} \mathrm{O} 25 \mathrm{~kg} \mathrm{ha}^{-1}$ \\
\hline
\end{tabular}

\subsection{Sample Collection and Analysis}

Soil sampling were collected before and after cultivation at depth $0-30 \mathrm{~cm}$ then it was analyzed in laboratories for certain soil physical and chemical properties including soil $\mathrm{pH}$ measured by using soil to water ratio 1:1 (National Soil Survey Center [NSSC], 1996). Electrical conductivity $\left(\mathrm{EC}_{\mathrm{e}}\right)$ was measured on water saturated extract (Rayment \& Lyons, 2011). Organic matter (OM) was measured by Walkley and Black method (Walkley \& Black, 1934). Available P was measured by Bray II method (Bray \& Kurtz, 1945). Exchangeable K was measured by extraction with $\mathrm{NH}_{4} \mathrm{OAc}$ at $\mathrm{pH} 7.0$ (Pratt, 1965) and cation exchange capacity (CEC) was measured on saturated extract using $\mathrm{NH}_{4} \mathrm{OAc}$ at $\mathrm{pH} 7.0$ (Chapman, 1965).

Plant data comprised growth, yield and yield component. Growth data included plant height and above ground biomass. Plant height was collected at 3, 6, 9 and 12 months after planting. Above ground biomass was collected at 12 month after planting. Yield and yield components were collected at 12 month after planting including fresh tuber yield, starch content, starch yield and concentration of total $\mathrm{N}, \mathrm{P}$ and $\mathrm{K}$ in fresh tuber yield.

\subsection{Statistical Analysis}

Plant data and soil properties under difference rate of chemical fertilizer and type of soil conditioners were analyzed for statistical significance by method of analysis of variance (ANOVA) and difference between means by Duncan's multiple range test (DMRT).

\section{Results and Discussion}

Effect of fertilizer management in combination with soil conditioners on soil properties, cassava growth, yield and yield components.

\subsection{Soil Properties}

Sole use of chemical fertilizer in various rates or combined with soil conditioners had highly significant effect on 
soil properties (Table 4) including soil $\mathrm{pH}$, electrical conductivity $\left(\mathrm{EC}_{\mathrm{e}}\right)$, organic matter $(\mathrm{OM})$, cation exchange capacity (CEC), available P and exchangeable K. Soil pH level was classified between moderately to slightly acid and found lowest soil $\mathrm{pH}$ for chemical fertilizer $100 \%$ combined with zeolite which was not different from chemical fertilizer combined with organic fertilizer rate $1,018.75 \mathrm{~kg} \mathrm{ha}^{-1}$. Lowest soil $\mathrm{pH}$ of chemical fertilizer $100 \%$ combined with zeolite was the result of ammonium sulfate (21-0-0) that can release $\mathrm{H}^{+}$from hydrolysis process and zeolite can absorb $\mathrm{H}^{+}$and another cation well. The phenomenon of soil $\mathrm{pH}$ reduction causing by nitrogen fertilizer has been verified by other researchers (Mitchell \& Smethurst, 2004; Kongkaew, 2007; Costa, 2012). Smaller effect on soil $\mathrm{pH}$ was found for chemical fertilizer combined with organic fertilizer rate $1,018.75 \mathrm{~kg} \mathrm{ha}^{-1}$. This treatment although applied chemical fertilizer at lower rate but the combination potentially released organic acids from decomposition of organic matter that could lower soil pH. (Kongkaew, 2007; Sampanpanish, 2012). Soil $\mathrm{EC}_{\mathrm{e}}$ level was not affected by this experiment (non-saline soil). The level of organic matter in soil after the experiment was classified between low to moderately low. Organic matter was highest for chemical fertilizer combined with organic fertilizer rate $1,018.75 \mathrm{~kg} \mathrm{ha}^{-1}$ followed by chemical fertilizer combined with organic fertilizer rate $762.5 \mathrm{~kg} \mathrm{ha}^{-1}$ and higher than conditioner treatments since organic fertilizer has organic matter more than soil conditioners (Kongkaew, 2007; Kaewkamthong et al., 2014; Guo et al., 2016). Cation exchange capacity after this experiment was found between moderately low to moderate levels. All treatments of chemical fertilizer combined with soil conditioners caused negligible effect on cation exchange capacity since the soils acquired additional cation exchange sites from soil conditioners. Levels of available P in soil were found between low to moderate but level of exchangeable $\mathrm{K}$ in soil is still very low due to leaching in coarse-textured soil and crop removal according to previous reports that consistently suggested that cassava drawn large amount of $\mathrm{K}$ from soil. The content of $P$ was not greatly affected by the treatments (Howeler \& Cadavid, 1983; Howeler, 1991; Kongkaew, 2007). Moreover, chemical fertilizer combined with organic fertilizer rate $1,018.75 \mathrm{~kg} \mathrm{ha}^{-1}$ resulted highest available $\mathrm{P}$ and exchangeable $\mathrm{K}$ in soil followed by chemical fertilizer $100 \%$ combined with zeolite and pumice respectively. Chemical fertilizer combined with organic fertilizer rate $1,018.75 \mathrm{~kg} \mathrm{ha}^{-1}$ contributed highest organic matter, available $\mathrm{P}$ and exchangeable $\mathrm{K}$ in soil due to the fact that organic fertilizer can reduce leaching of plant nutrients and release plant nutrients to soil. Besides, organic fertilizer has various plant nutrients in organic form that continuously decomposed by microbial activity and released plant nutrients in mineral form. Therefore the combination results increase in levels of organic matter, available $\mathrm{P}$ and exchangeable $\mathrm{K}$ in soil, which corresponds to previous reports (Kaewkamthong et al., 2014; Brady \& Weil, 2008).

\subsection{Cassava Growth}

The results revealed that application of sole chemical fertilizer at various rates or combined with soil conditioners significantly affected plant height and above ground biomass at 3 and 6 months after planting (Figure 1). Application of chemical fertilizer in combination with organic fertilizer at $1,018.75 \mathrm{~kg} \mathrm{ha}^{-1}$ gave highest plant height and was not difference from chemical fertilizer $100 \%$ applied solely or combined with zeolite and pumice. Furthermore, at 9 and 12 month after planting, application of chemical fertilizer combined with organic fertilizer rate $1,018.75 \mathrm{~kg} \mathrm{ha}^{-1}$ gave highest plant height and above ground biomass (Figure 1 and 2), and was not different from chemical fertilizer 100\% combined with zeolite. During the period 3 and 6 months, all treatment receiving chemical fertilizer $75 \%$ applied solely or combined with soil conditioners gave insufficient plant nutrients for growth. Thus, plant height of cassava received chemical fertilizer $100 \%$ was better than cassava received chemical fertilizer 75\% (DOA, 2005; Kongkaew, 2007), during this period considering on plant heights revealed that nutrient leaching was not pronounced but during 9 and 12 month periods, cumulative nutrient leaching in coarse-textured soil contributed significant loss of nutrients for plant uptake (Duangpatra, 1988; Astier et al., 2006). So application of sole chemical fertilizer in coarse-textured soil plant nutrient could be easier leached than application of chemical fertilizer in combination with soil conditioner except pumice since pumice has lowest cation exchange capacity among soil conditioners used in this experiment (Panuccio et al., 2009; Duangpatra, 2010). Moreover, chemical fertilizer combined with organic fertilizer rate $1,018.75 \mathrm{~kg} \mathrm{ha}^{-1}$ gave highest plant height and above ground biomass at all periods due to the fact that organic matter has more plant nutrients in organic form than other soil conditioners that continuously decomposed and released for plant, according to previous reported (Kaewkamthong et al., 2014; Brady \& Weil, 2008). Observed plant height at all periods and above ground biomass were affected by rate of chemical fertilizer, application of sole chemical fertilizer $100 \%$ or combined with soil conditioners gave plant height and above ground biomass more than application of sole chemical fertilizer $75 \%$ or combined with soil conditioners (Kongkaew, 2007; Costa, 2012; Kaewkamthong et al., 2014). On the other hand, control treatment gave the lowest above ground biomass and plant heights in all growth stages since plant nutrients in soil was insufficient for plant. 
Table 4. Soil properties as affected by fertilizer management used in combination with soil conditioners

\begin{tabular}{ccccccc}
\hline Treatment & $\mathrm{pH}$ & $\begin{array}{c}\mathrm{EC}_{\mathrm{e}} \\
\left(\mathrm{dS} \mathrm{m}^{-1}\right)\end{array}$ & $\begin{array}{c}\mathrm{OM} \\
(\%)\end{array}$ & $\begin{array}{c}\mathrm{CEC} \\
\left(\mathrm{cmol} \mathrm{kg}^{-1}\right)\end{array}$ & $\begin{array}{c}\text { Available P } \\
\left(\mathrm{mg} \mathrm{kg}^{-1}\right)\end{array}$ & $\begin{array}{c}\text { Exchangeable K } \\
\left(\mathrm{mg} \mathrm{kg}^{-1}\right)\end{array}$ \\
\hline Initial soil & 6.15 & 0.22 & 0.45 & 2.42 & 5.13 & 16.62 \\
\hline T1 & $6.12 \mathrm{~b}$ & $0.24 \mathrm{f}$ & $0.50 \mathrm{f}$ & $2.85 \mathrm{~d}$ & $5.22 \mathrm{~g}$ & $16.77 \mathrm{e}$ \\
$\mathrm{T} 2$ & $5.94 \mathrm{c}$ & $1.01 \mathrm{~d}$ & $0.75 \mathrm{~cd}$ & $10.58 \mathrm{bc}$ & $12.46 \mathrm{~cd}$ & $24.85 \mathrm{~b}$ \\
$\mathrm{~T} 3$ & $5.76 \mathrm{~d}$ & $1.62 \mathrm{a}$ & $0.84 \mathrm{c}$ & $12.36 \mathrm{a}$ & $13.54 \mathrm{~b}$ & $26.42 \mathrm{ab}$ \\
T4 & $6.10 \mathrm{~b}$ & $1.46 \mathrm{ab}$ & $0.76 \mathrm{~cd}$ & $11.42 \mathrm{ab}$ & $12.87 \mathrm{bc}$ & $25.88 \mathrm{ab}$ \\
T5 & $5.86 \mathrm{~cd}$ & $1.58 \mathrm{a}$ & $1.36 \mathrm{a}$ & $12.12 \mathrm{ab}$ & $14.56 \mathrm{a}$ & $26.85 \mathrm{a}$ \\
$\mathrm{T} 6$ & $6.22 \mathrm{ab}$ & $0.68 \mathrm{e}$ & $0.64 \mathrm{e}$ & $9.45 \mathrm{c}$ & $8.89 \mathrm{f}$ & $18.51 \mathrm{de}$ \\
T7 & $6.18 \mathrm{ab}$ & $1.38 \mathrm{bc}$ & $0.71 \mathrm{de}$ & $11.89 \mathrm{ab}$ & $10.56 \mathrm{e}$ & $19.68 \mathrm{~cd}$ \\
T8 & $6.28 \mathrm{a}$ & $1.26 \mathrm{c}$ & $0.68 \mathrm{de}$ & $10.85 \mathrm{abc}$ & $9.25 \mathrm{f}$ & $18.99 \mathrm{~cd}$ \\
T9 & $6.15 \mathrm{ab}$ & $1.32 \mathrm{bc}$ & $1.17 \mathrm{~b}$ & $11.68 \mathrm{ab}$ & $11.87 \mathrm{~d}$ & $20.65 \mathrm{c}$ \\
\hline F-test & $* *$ & $* *$ & $* *$ & $* *$ & $* *$ & $* *$
\end{tabular}

Note. $* *$ significant at 0.01 probability levels, the figures containing the same letter(s) in the same column indicated a non-significant different according Duncan's Multiple Range Test (DMRT).

\subsection{Yield and Yield Components}

The results revealed that application of sole chemical fertilizer at various rates or combined with soil conditioners had highly significant effect on fresh tuber yield, starch content and starch yield (Figure 2). At 12 month after planting, application of chemical fertilizer combined with organic fertilizer rate $1,018.75 \mathrm{~kg} \mathrm{ha}^{-1}$ gave the highest fresh tuber yield and was not difference from chemical fertilizer $100 \%$ combined with zeolite, application of chemical fertilizer $75 \%$ gave lower fresh tuber yield than application of chemical fertilizer $100 \%$ (Costa, 2012). Moreover, zeolite and organic fertilizer have higher cation exchange capacity than pumice that can reduce plant nutrient leaching better than pumice and sole chemical fertilizer (Panuccio et al., 2009; Duangpatra, 2010). Starch content of all treatments of sole chemical fertilizer at various rates or combined with soil conditioners was not different, being in the range of 27.56-26.42\%. The result agreed with another report (Kaewkamthong et al., 2014). Furthermore, application of chemical fertilizer combined with organic fertilizer rate $1,018.75 \mathrm{~kg} \mathrm{ha}^{-1}$ gave highest starch yield and was not different from application of chemical fertilizer $100 \%$ combined with zeolite and pumice. Chemical fertilizer combined with organic fertilizer gave better fresh tuber yield, starch content and starch yield than used in combination with other soil conditioners. This contributed to the fact that organic fertilizer contains organic matter and plant nutrients more than other soil conditioners and can improve soil physical properties and enhance yield and yield components as reported previously (Kaewkamthong et al., 2014; Brady \& Weil, 2008). Nevertheless, control treatment gave the lowest fresh tuber yield, starch content and starch yield in all growth stage because plant nutrient in soil was insufficient for plant.

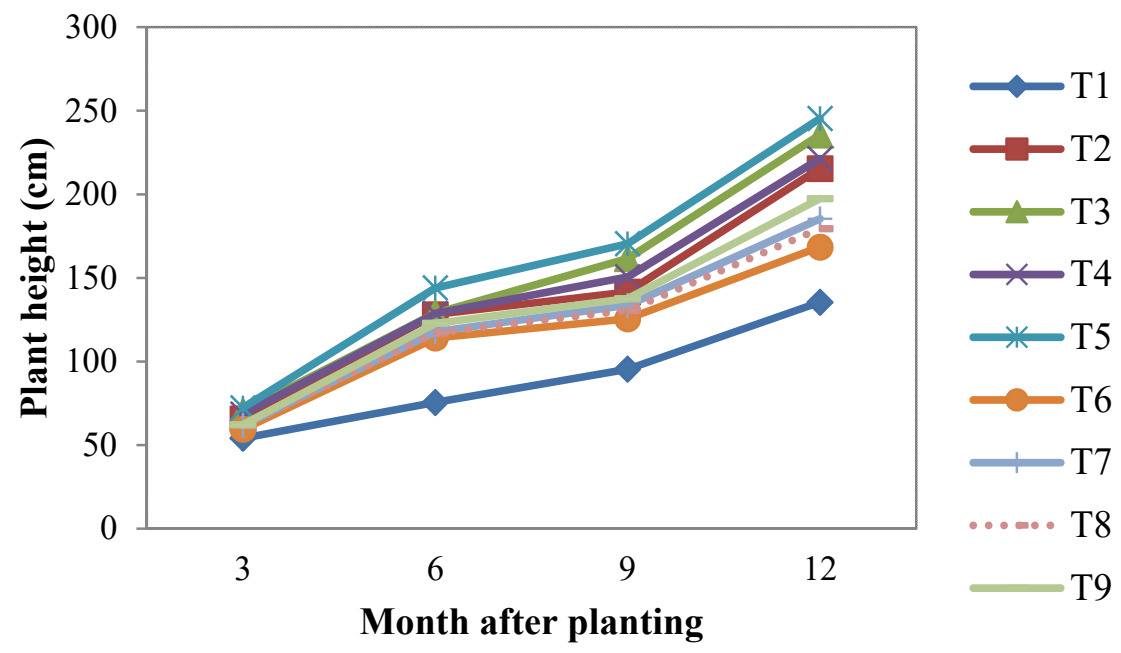

Figure 1. Plant height of cassava measured at 3, 6, 9 and 12 month after planting 

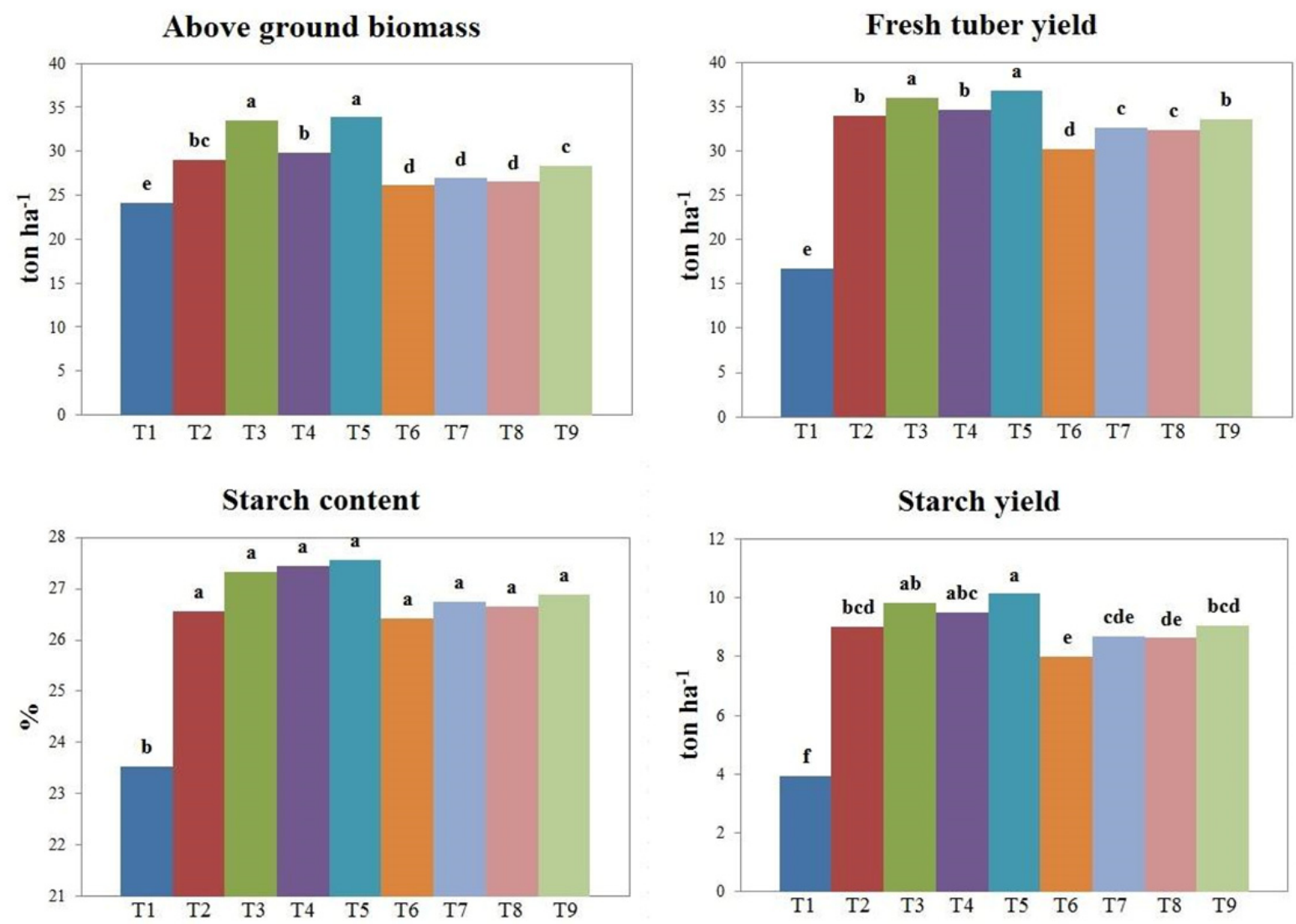

Figure 2. Above ground biomass, fresh tuber yield, starch content and starch yield of cassava at 12 month after planting

\subsection{Concentration of Primary Nutrient}

Considering the concentration of primary nutrient, it was found that application of sole chemical fertilizer at various rates or combined with soil conditioners had highly significant effect on total $\mathrm{N}, \mathrm{P}$ and $\mathrm{K}$ content in fresh tuber yield (Figure 3). Application of chemical fertilizer combined with organic fertilizer rate $1,018.75 \mathrm{~kg} \mathrm{ha}^{-1}$ gave highest total $\mathrm{N}$ and $\mathrm{K}$, and was not different from chemical fertilizer $100 \%$ combined with zeolite and pumice. Although, chemical fertilizer combined with organic fertilizer rate $1,018.75 \mathrm{~kg} \mathrm{ha}^{-1}$ gave highest total $\mathrm{P}$, and was not difference from applied chemical fertilizer 100\% combined with zeolite. Because zeolite and organic fertilizer can reduce plant nutrient leaching better than pumice according to their higher CEC (Panuccio et al., 2009; Duangpatra, 2010), therefore, cassava can uptake plant nutrient and accumulated in fresh tuber better. Higher accumulation of $\mathrm{K}$ were detected because cassava could accumulate highest $\mathrm{K}$ in tuber, followed by total $\mathrm{N}$ and P respectively, which corresponded with previous reports (Howeler \& Cadavid, 1983; Howeler, 1991). 

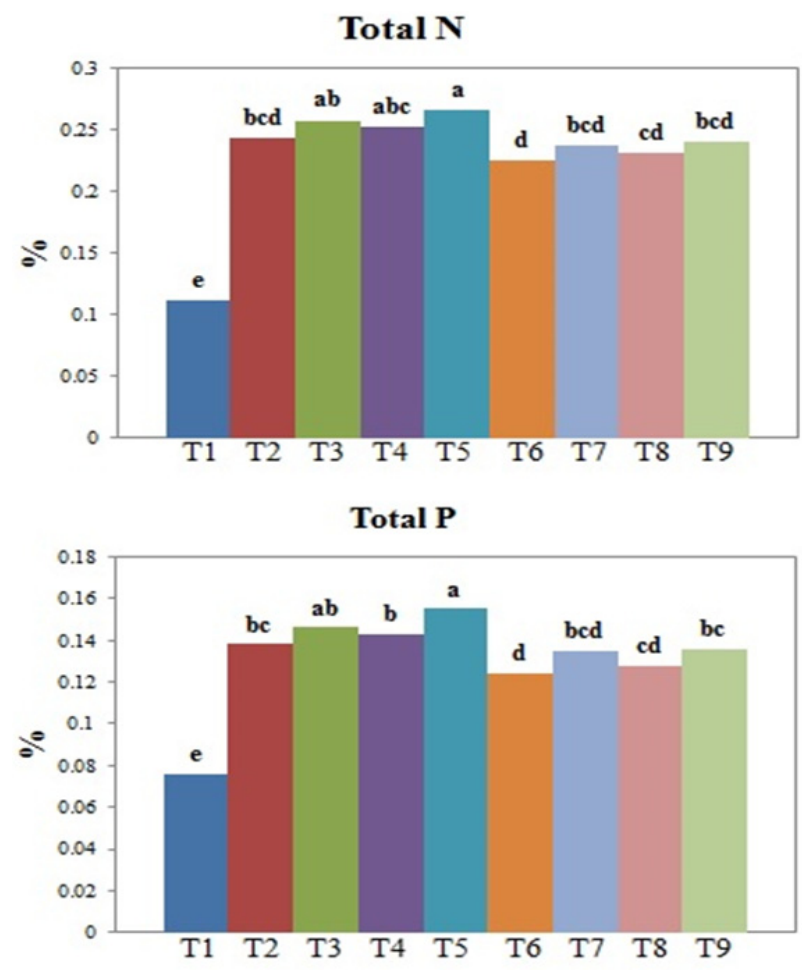

Total K

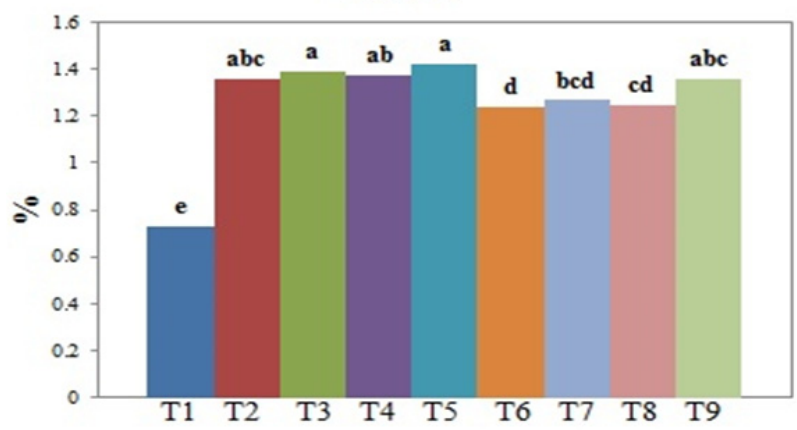

Figure 3. Concentration of primary nutrient in cassava fresh tuber yield

\section{Conclusion}

The results of this experiment suggested that chemical fertilizer combined with organic fertilizer rate $1,018.75 \mathrm{~kg}$ $\mathrm{ha}^{-1}$ was suitable for cassava cultivated in coarse-textured soil since it gave highest plant height, above ground biomass, fresh tuber yield, starch content and starch yield. However, such treatment was not different from chemical fertilizer $100 \%$ combined with zeolite. The treatments of chemical fertilizer $100 \%$ combined with pumice and chemical fertilizer $75 \%$ combined with soil conditioners were less efficient. Furthermore, chemical fertilizer combined with organic fertilizer rate $1,018.75 \mathrm{~kg} \mathrm{ha}^{-1}$ could increase plant nutrient and organic matter in soil better than combine use with zeolite and pumice, respectively. Moreover, soil $\mathrm{pH}$ was found to decrease when applied sole chemical fertilizer at high rate or use in combination with soil conditioners.

\section{Acknowledgments}

This research was supported by Graduate School of Kasetsart University, Thailand .Furthermore, many thanks to Department of Soil Science, Faculty of Agriculture at Kamphaeng Saen for support tool and equipment in this research.

\section{References}

Agassi, M., Morin, J., \& Shainberg, I. (1990). Slope, aspect and phosphogypsum effects on runoff and erosion. Soil Sci. Soc. Am. J., 54, 1102-1106. http://dx.doi.org/10.2136/sssaj1990.03615995005400040030x 
Anusontpornperm, S., Nortcliff, S., \& Kheoruenromne, I. (2005). Hardpan formation of some coarse-textured upland soils in Thailand. Proceeding of the International Symposium on Management of Tropical Sandy Soils from Sustainable Agriculture, Khon Kaen, Thailand.

Astier, M., Maass, J. M., Etchevers Barra, J. D., Pena, J. J., \& Gonzalez, F. (2006). Short-term green manure and tillage management effects on maize yield and soil quality in an Andisol. Soil Till. Res., 88, 153-159. http://dx.doi.org/10.1016/j.still.2005.05.003

Brady, N. C., \& Weil, R. R. (2008). The Nature and Properties of Soils (14th Eds.). New Jersey: Prentice Hall.

Bray, R. A., \& Kurtz, L. T. (1945). Determination of total, organic and available forms of phosphorus in soils. Soil Science, 59, 39-45.

Buarach, K., Thongjoo, C., Udomprasert, N., \& Amkha, S. (2014). Effects of tillage system and soil organic matter amendment on growth, yield of Pathumthani 80 rice and carbon sequestration in paddy soil. Modern Applied Science, 8(4), 1-7. http://dx.doi.org/10.5539/mas.v8n4p1

Celik, I., Gunal, H., Budak, M., \& Akpinar, C. (2010). Effects of long-term organic and mineral fertilizers on bulk density and penetration resistance in semi-arid Mediterranean soil conditions. Geoderma, 160, 236-243. $\mathrm{http}: / / \mathrm{dx}$.doi.org/10.1016/j.geoderma.2010.09.028

Chapman, H. D. (1965). Cation-exchange capacity. In C. A. Black (Ed.), Methods of Soil Analysis - Chemical and Microbiological Properties, Agronomy (Vol. 9, pp. 891-901). Madison, Wisconsin: American Society of Agronomy.

Chen, Z., Chen, W., Li, C., Pu, Y., \& Sun, H. (2016). Effects of polyacrylamide on soil erosion and nutrient losses from substrate material in steep rocky slope stabilization projects. Sci. Total Environ., 554-555, 26-33. http://dx.doi.org/10.1016/j.scitotenv.2016.02.173

Costa, M. C. G. (2012). Soil and crop responses to lime and fertilizers in a fire-free land use system for smallholdings in the northern Brazilian Amazon. Soil Till. Res., 121, 27-37. http://dx.doi.org/10.1016/j.still.2012.01.017

Department of Agriculture. (2005). Fertilizer recommendation for economic crop. Bangkok, Thailand: Department of Agriculture.

Duangpatra, P. (1988). Soil and climatic characterization of major cassava growing areas on Thailand. Proceedings of the CIAT Workshop on Cassava Breeding and Agronomy Research in Asia (pp. 157-184). Bangkok, Thailand.

Duangpatra, P. (2010). Soil Conditioners. Bangkok, Thailand: KASETSART UNIVERSITY PRESS.

Gama Castro, J. E., Solleiro Rebolledo, E., \& Vallejo Gómez, E. (2000). Weathered pumice influence on selected alluvial soil properties in west Nayarit, Mexico. Soil Till. Res., 55, 143-165. http://dx.doi.org/10.1016/S0167-1987(00)00114-8

Gholamhoseini, M., Ghalavand, A., Khodaei, J. A., Dolatabadian, A., Zakikhani, H., \& Farmanbar, E. (2013). Zeolite-amended cattle manure effects on sunflower yield, seed quality, water use efficiency and nutrient leaching .Soil Till. Res., 126, 193-202. http://dx.doi.org/10.1016/j.still.2012.08.002

Guo, L., Wu, G., Li, Y., Li, C., Liu, W., Meng, J., ... Jiang, G. (2016). Effects of cattle manure compost combined with chemical fertilizer on topsoil organic matter, bulk density and earthworm activity in awheat-maize rotation system in Eastern China. Soil Till. Res., 156, 140-147. http://dx.doi.org/10.1016/j.still.2015.10.010

Howeler, R. H., \& Cadavid, L. F. (1983). Accumulation and distribution of dry matter and nutrients during a 12-month growth cycle of cassava. Field Crop. Res., 7, 123-139. http://dx.doi.org/10.1016/0378-4290(83)90017-5

Howeler, R. H. (1991). Long-term effect of cassava cultivation on soil productivity. Field Crop. Res., 26, 1-18. http://dx.doi.org/10.1016/0378-4290(91)90053-X

Kaewkamthong, Y., Thanachit, S., Anusontpornperm, S., \& Wiriyakitnateekul, W. (2014). Alleviation of Soil Compaction Problem for Growing Cassava on a Typic Paleustult, Northeast Thailand. Asian J. Crop Sci., 6, 334-344. http://dx.doi.org/10.3923/ajcs.2014.334.344

Kongkaew, T. (2007). Utilization of by-Product of Monosodium Glutamate Industry (Ami-Ami) as Fertilizer for Cassava. Khon Kaen Agric. J., 35, 411-418.

Mitchell, A. D., \& Smethurst, P. J. (2004). Surface soil changes in base cation concentrations in fertilised 
hardwood and softwood plantations in Australia. For. Ecol. Manage., 191, 253-265. http://dx.doi.org/10.1016/j.foreco.2003.12.011

National Soil Survey Center. (1996). Soil survey laboratory methods manual. Soil Survey Investigations Report (No. 42, Version 3.0), Natural Conservation Service, USDA.

Office of Agricultural Economics. (2014). Agricultural statistics of Thailand 2014. Bangkok, Thailand: Office of Agricultural Economics.

Panuccio, M. R., Sorgona, A., Rizzo, M., \& Cacco, G. (2009). Cadmium adsorption on vermiculite, zeolites and pumice: Batch experimental studies. J. Environ. Manage, 90, 364-374. http://dx.doi.org/10.1016/j.jenvman.2007.10.005

Pratt, P. F. (1965). Potassium. In Method of Soil Analysis, Part II. Chemical and Microbiological Properties, Black, C. A. (Ed.). American Society of Agronomy, Madison, WI., USA., 1023-1031.

Putthacharoen, S., Howeler, R. H., Jantawat, S., \& Vichukit, V. (1998). Nutrient uptake and soil erosion losses in cassava and six other crops in a Psamment in eastern Thailand. Field Crop. Res., 57, 113-126. http://dx.doi.org/10.1016/S0378-4290(97)00119-6

Ramesh, K., \& Reddy, D. D. (2011). Chapter Four - Zeolites and Their Potential Uses in Agriculture. Adv. Agron., 113, 219-241. http://dx.doi.org/10.1016/B978-0-12-386473-4.00004-X

Rayment, G. E., \& Lyons, D. J. (2011). Soil chemical methods-Australasia. Collingwood, Australia: CSIRO Publishing.

Sampanpanish, P. (2012). Effect of organic fertilizer on $\mathrm{CO}_{2}, \mathrm{CH}_{4}$ and $\mathrm{N}_{2} \mathrm{O}$ emissions in a paddy field .Modern Applied Science, 6(12), 13-21. http://dx.doi.org/10.5539/mas.v6n12p13

Tongglum, A., Suriyapan, P., \& Howeler, R. H. (2000). Cassava agronomy research and adoption of improved practices in Thailand: Major achievements during the past 35 years. Proceedings of the 6th Regional Workshop on Cassava's Potential in Asia in the 21st Century: Present Situation and Future Research and Deveropment Needs (pp. 228-258). Ho Chi Minh City, Vietnam.

Walkley, A., \& Black, I. A. (1934). An examination of the Degtjareff method fordetermining soil organic matter, and a proposed modification of thechromic acid titration method. Soil Science, 37, 29-38. http://dx.doi.org/10.1097/00010694-193401000-00003

Warrington, D., Shainberg, I., Agassi, M., \& Morin, J. (1989). Slope and Phosphogypsum's Effects on Runoff

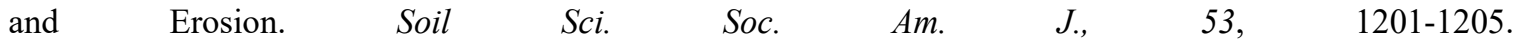
http://dx.doi.org/10.2136/sssaj1989.03615995005300040035x

Wu, C., Li, W., Wang, K., \& Li, Y. (2015). Usage of pumice as bulking agent in sewage sludge composting. Bioresource Technol., 190, 516-521. http://dx.doi.org/10.1016/j.biortech.2015.03.104

\section{Copyrights}

Copyright for this article is retained by the author(s), with first publication rights granted to the journal.

This is an open-access article distributed under the terms and conditions of the Creative Commons Attribution license (http://creativecommons.org/licenses/by/4.0/). 